\title{
legelivet
}

På disse sidene i Tidsskriftet - legelivet - finner du stoff om legers liv.

Her er det presentasjon av arbeidssteder, nyhetssaker, nye doktorgrader,

nye spesialister og minneord. Alt samlet på ett sted - så du kan følge enda bedre med.

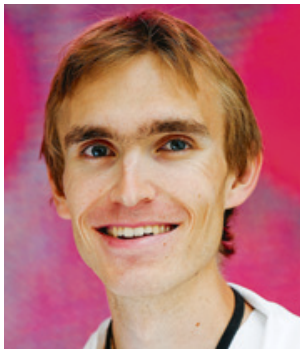

Frederik Emil Juul. Foto: Jon Olav Nesvold

Frederik Emil Juul (f. 1989) er turnuslege ved Sykehuset Innlandet, Hamar.

\section{$\AA$ se seg selv i pasienten}

Pasientens syke- og livshistorie kan føles som et speilbilde av ens egen historie.

Vi møter stadig pasienter og pårørende $i$ alvorlige og triste situasjoner. Hendelsene kan i ulik grad berøre oss ved at de vekker minner om egne relasjoner og eget liv. Avhengig av hva legen selv har opplevd, vil han eksempelvis kunne identifisere seg med den inkontinente pasienten som vet hvor alle byens toaletter er lokalisert, eller med tenåringen som sitter igjen etter farens selvmord.

Noen pasienter spør om legen skjønner hva han/hun opplever. Svaret er ofte ja. Men i hvilken grad betyr det at man opplever pasientens situasjon? Selv om det finnes unntak (1), vil særlig yngre leger, som nødvendigvis har kommet seg relativt uproblematisk gjennom videregående skole og universitetsutdanning, ha et mindre repertoar av (negative) livserfaringer som bakgrunn for å kunne sette seg inn i pasientens situasjon. Enkelte argumenterer for at unge ikke burde gå rett fra videregående skole til medisinstudiet, blant annet fordi de mangler livserfaring (2).

Har det så en betydning at legen identifiserer seg med pasienten? En veletablert lege med en sunn livsstil vil muligens ha større vansker med å forstå hvorfor den røykende kolspasienten uten fullført grunnskole ikke vil slutte å røyke eller hvorfor han ikke vil søke arbeid. På den annen side kan en sunn person som er blitt syk, bevisstgjøre legen om hans egen sårbarhet for sykdom. For indirekte å beskytte seg selv og fordi pasientens sunne livsstil «fortjener» det, vil legen kanskje gi pasienten en tettere oppfølging. Kort sagt - om man ser seg selv i pasientens situasjon, skal man aktivt bruke sine egne erfaringer til å møte og forstå ham, eller skal man forholde seg objektiv og profesjonell så langt det lar seg gjøre?

Uansett, til tross for en nærmest autentisk identifisering med pasienten, kan vi aldri fullstendig innta hans posisjon. Boken The House of God synes jeg har en god beskrivelse av dette: «Law number four: The patient is the one with the disease» (3).

\section{Frederik Emil Juul}

fejuul.medisin@gmail.com

Litteratur

1. Schei E. Medisinstudent klok av skade. Tidsskr Nor Legeforen 2016; 136: 908-10.

2. Kjellevold K. Professor vil ha 21 års aldersgrense på legestudiet. Bergens Tidende 25.3.2015. www.bt.no/nyheter/lokalt/Professorvil-ha-21-ars-aldersgrense-pa-legestudiet298399b.html (13.11.2016).

3. Shem S. The House of God. New York: Dell, 1978. 